\title{
The Hymenochaetales: a revision of the European poroid taxa
}

\author{
JEAN-LOUIS FIASSON and TUOMO NIEMELÄ
}

\begin{abstract}
FIASSON, J.L. \& NIEMELÄ, T. 1984: The Hymenochaetales: a revision of the European poroid taxa. - Karstenia 24: 14-28.

The relationships of the European poroid Hymenochaetales were assessed from an array of 20 characters: 14 morphological and microscopical features of the fruit body, cultural type and nuclear behaviour of the secondary mycelium, extractable styrylpyrone contents of the basidiocarp, electrophoretic protein patterns and type of enzymatic ability of the mycelium. Taxonomic information was retrieved in two ways: phenetic and phylogenetic.

As a result, the Hymenochaetales are divided into two suborders, Phaeolinae Fiasson \& Niemelä and Hymenochaetinae Fiasson \& Niemelä, the former comprising one family (Phaeolaceae Jül.) and the latter three (Hymenochaetaceae Donk, Inonotaceae Fiasson \& Niemelä and Phellinaceae Jül.). The following genera are accepted to accommodate the European species which were formerly included in the genera of Inonotus and Phellinus: Inonotus Karst., Inocutis Fiasson \& Niemelä (formerly the Inonotus rheades complex), Inonotopsis Parm., Phylloporia Murr. (P. ribis complex), Fomitiporia Murr. ( $P$. robustus complex), Porodaedalea Murr. ( $P$. pini complex), Ochroporus J.Schroet. (P. igniarius complex), Phellinidium (Kotl.) Fiasson \& Niemelä ( $P$. ferrugineofuscus and its allies), Phellinus Quél. (P. torulosus), Fuscoporia Murr. (P. ferreus and its allies), and Fulvifomes Murr. ( $P$. rimosus complex). Within these genera, 23 new combinations of species names are proposed. The concepts of the genera and families are emended, and the affinities of the Hymenochaetales to the other groups of fungi are discussed.
\end{abstract}

Jean-Louis Fiasson, Université Claude-Bernard Lyon-I, Biologie Végétale (Bât. 741) Laboratoire de Mycochimie, 43 Boulevard du 11 Novembre 1918, F-69622 Villeurbanne, France

Tuomo Niemelä, Department of Botany, University of Helsinki, Unioninkatu 44, SF00170 Helsinki, Finland

\section{The Hymenochaetales}

The entity of the hymenochaetaceous fungi first arose as the Série des Igniaires of Patouillard (1900). This united genera which varied in their basidiocarp morphology and hymenial configurations, but all possessed setae. Actually this peculiar type of cystidia is missing in some species and even genera of the group, but the golden to brown colouration of the basidiocarp and its darkening in potassium hydroxide ('xanthochroic reaction') are shared by virtually all of them. It was as the Xanthochroic Series that Patouillard's Igniaires were finally acknowledged by Corner (1948), while Donk (1948) recognized the group as the family Hymenochaetaceae. They were raised to the rank of order as the Hymenochaetales by Oberwinkler (1977). Jülich (1981) merely raised some old dichotomies of the determination keys to family rank, without discussion and without any new information.

Recherches Chimiotaxinomiques sur les Champignons, 48 (for 47, see Fiasson \& Bernillon 1983).
In its present scope, the order Hymenochaetales includes, e.g., Asterodon Pat., hydnoid with both asterosetae and ordinary ones, the corticioid Hymenochaete Lév, and the irpicoid Hydnochaete Bres., which both lack the asterosetae, and various poroid genera. Of the poroid genera, those most often mentioned are Phaeolus Pat,, Coltricia S.F.Gray, Onnia Karst., Inonotus Karst., Phylloporia Murr. and Phellinus Quél., the first three often being stipitate and growing mainly on roots of various trees, while the last three are dimidiate to resupinate and grow on trunks or branches. The distinction between Inonotus and Phellinus, based originally on the colour of the spores (Bourdot \& Galzin 1928), then on the hardness and perenniality of the basidiocarp in Phellinus (Pilát 1936-1942), now rests (since Cunningham 1947) on the miticity. This in turn has led to a revival of Phylloporia Murr., which was accepted as the genus for the species widely known as Phellinus ribis (Schum.: Fr.) Karst., a perennial but monomitic polypore (Ryvarden 1978). The demarcation between the generative and skeletal hyphae is often vague to nonexistent in this group (Jahn 1981), and so the 
distinction between Inonotus and Phellinus again appears to become a problem.

The naturalness of this order is underlined by the constant lack of clamp connections (Kühner 1950a) and, with the exception of Phaeolus schweinitzii (Fr.) Pat., whose taxonomical position has recently been discussed (Parmasto \& Parmasto 1979, Jülich 1981), by the production of white-rot and the uniformity of the cultural characters (Nobles 1948, 1965).

\section{A new approach}

We approached the taxonomical problems of this group from diverse viewpoints, studying the styrylpyrone pigments of the basidiocarp (Fiasson et al. 1977, Fiasson \& Bernillon 1977, Fiasson 1982), the enzymatic activities and proteinograms of the secondary mycelium (Fiasson \& Bernillon 1983), and the morphological and anatomical features, especially those of the basidiocarp (Fiasson \& David 1983). We also examined the nuclear behaviour of the secondary mycelium, a noteworthy evolutionary character (Boidin 1971, Kühner 1980). The basic material consisted of the European poroid taxa, and the observations published here deal mainly with them. To widen the scope of the study and allow us to place the results in a more general context, over one hundred exotic samples of the order were examined. Those results have not yet been published, but will be referred to in the following discussion. Some work on polypores other than the Hymenochaetales (David \& Fiasson 1977) gave us personal acquaintance with some out-groups.

This paper is a synthesis of the studies of J.L. Fiasson. T. Niemelä joined in the project at its final stage, supporting the division of the genus Phellinus, and sharing the responsibility for this inevitable step.

The conclusions are mainly based on 20 characters, listed in Table 1. All these characters (except the nuclear behaviour: from Kühner $1950 \mathrm{~b}$ and personal observations) have been previously described and discussed, and the relevant conclusions published (Fiasson 1982, 1983, Fiasson \& Bernillon 1983, Fiasson \& David 1983). This data matrix was analysed in two independent ways: by using a computerized taxometric analysis without weighting of the characters, and by drawing a phylogenetic groundplan in which a relative apomorphic value is attributed to each character state.

\section{Materials and methods}

The fungal material. The origin of the specimens studied was described by David, Dequatre and Fiasson (1982) and Fiasson (1982).

Nuclear behaviour. We followed the techniques of Kühner (1950b), in which the mycelium, in a drop of nutritive medium, was placed directly on a microscope slide and covered with a film of collodion, but Giemsa staining was used concurrently with the original ferric haematoxylin.

Mathematical treatment. Multiple correspondence analysis (Lebart et al. 1977) was followed by a TAXI automatic classification, using the computer programs of the Biometry Laboratory, University of Lyon-I, written by R. Fages.
The groundplan analysis was made according to Wiley (1981).

The data matrix

- Table 1

Characters $\mathbf{1 - 1 2}$ and $\mathbf{1 9 - 2 0}$ are features of the basidiocarp: the various character states were defined and discussed by Fiasson and David (1983). The hyphal system and perenniality practically coincided in an initial run with the morphological features alone and were merged here; the same goes for the size and wall thicknesses of the spores.

Character $\mathbf{1 3}$ is the 'type of culture'. At first we had 12 characters (32 character states) to describe the secondary mycelium, but it turned out to be unrealistic to treat them on a par with those of the basidiocarp, which are richer and more informative. The first analysis of the cultural characters distributed the species in four groups (Fiasson \& David 1983), and it was decided to treat these as the four tentative character states of a single character. The 'type of culture' as a whole is thus given the same weight as a single feature of the basidiocarp (e.g., shape, miticity). This 'downgrading' of the mycelial characters is further justified by the reservations made about their reliability (Fiasson \& David 1983).

Characters $\mathbf{1 4}$ and $\mathbf{1 5}$ are the 'proteinogram pattern' and the 'API' pattern of the secondary mycelium (Fiasson \& Bernillon 1983). As each enzymatic activity (revealed here by API tests) and each individual protein (as seen in disc electrophoresis) can be coded by a single gene/allele, it would be inconsistent to put them on the same level as the morphological features, most of which have more complex determinants. So the two sets of data were submitted separately to clustering analysis. As regards the definition of their taxonomical significance (Fiasson \& Bernillon 1983), it appears reasonable to treat the group to which each species belongs as a character state and each of the two arrays of data as a single character.

Character $\mathbf{1 6}$ is the type of nuclear behaviour in the secondary mycelium. Personal studies with hundreds of slides allow us to agree with the original observations of Kühner (1950b). The patterns distinguished can be regrouped in three classes:

Binucleate: Each cell constantly containing a dikaryon.

Oligonucleate: $4-8(-10)$ nuclei in the terminal cells, the number falling rapidly to $(2-) 3(-4)$ in the following cells.

Coenocytic: Terminal cells with 16 to $40(-90)$ nuclei, this number decreasing slowly and progressively from cell to cell to $(4-) 8-12(-20)$ in those far from the hyphal apices.

Characters 17 and $\mathbf{1 8}$ refer, respectively, to the character and yield of the extractable styrylpyrones in the basidiocarp. Qualitatively, due to possible cooccurrence of hispidin and one or both of its two recognized dimers $\left(3,14^{\prime}\right.$-bishispidinyl and hypholomin B), five different pigment patterns were found (Fiasson 1982):

Hispidin and both dimers;

Hispidin and hypholomin B;

Hispidin and 3,14'-bishispidinyl;

Hispidin alone;

Absence of identifiable extractable styrylpyrones. 
The quantitative viewpoint is often disregarded by phytochemists on the assumption that what counts is only the presence of the gene(s) of the biosynthetic pathway whose terminal products are observed. But the yield may be genetically determined, and the ability to accumulate secondary metabolites requires adaptations and processes possessing their own genes (Hegnauer 1976).

\section{Phenetic analysis}

\section{Justification}

When a systematist decides to give more weight to a certain character and considers it taxonomically critical, he makes his choice after survey of the whole array of available data. However, this choice cannot be free from subjectivity: it may be influenced by

Table 1. Discriminative description of 36 European poroid hymenochaetaceous fungi by 20 characters.

\begin{tabular}{|c|c|c|c|c|c|c|c|c|c|c|c|c|c|c|c|c|c|c|c|c|}
\hline \multirow{2}{*}{\multicolumn{21}{|c|}{$\begin{array}{l}\text { Character } \\
\text { Spries }\end{array}$}} \\
\hline & & & & & & & & & & & & & & & & & & & & \\
\hline Ph liinus chrysoloma & 3 & 1 & 3 & 3 & 1 & 1 & 3 & 2 & 2 & 2 & 1 & 2 & 1 & 2 & 3 & 3 & & & & 2 \\
\hline - onchatus & 3 & 2 & 3 & 3 & 1 & 4 & 3 & 6 & 1 & 1 & 3 & 1 & 1 & 2 & 2 & 3 & & & & 2 \\
\hline -- contiguus & 1 & 2 & 2 & 2 & 1 & 4 & 3 & 6 & 1 & 1 & 3 & 1 & 1 & 2 & 2 & 1 & & & & 2 \\
\hline - erectus & 4 & 2 & 1 & 1 & 1 & 1 & 3 & 1 & 2 & 3 & 1 & 3 & 1 & 1 & 1 & 3 & & & & 2 \\
\hline - ferreus & 1 & 2 & 2 & 2 & 1 & 4 & 3 & 1 & 1 & 1 & 3 & 1 & 1 & 2 & 2 & 1 & & & & 2 \\
\hline - ferrugineofuscus & 1 & $\overline{1}$ & 2 & 2 & 1 & 3 & 1 & 7 & 1 & 1 & 3 & 1 & 1 & 2 & 2 & 2 & & & & 2 \\
\hline - ferruginosus & 1 & 2 & 2 & 2 & 1 & 4 & 4 & 5 & 1 & 1 & 2 & 1 & 1 & 2 & 1 & 1 & & & & \\
\hline - hartigii & 5 & 1 & 1 & 1 & 1 & 1 & 2 & 1 & 2 & 3 & 1 & 3 & 1 & 1 & 1 & 3 & & & & 2 \\
\hline - igniarius & 4 & 2 & 3 & 3 & 3 & 4 & 3 & 3 & 1 & 1 & 2 & 2 & 2 & 2 & 3 & 3 & & & & 2 \\
\hline - laevigatus & 2 & 2 & 3 & 3 & 1 & 1 & 3 & 1 & 1 & 2 & 2 & 2 & 2 & 2 & 3 & 3 & & & & \\
\hline - lundellii & 2 & 2 & 3 & 3 & 1 & 4 & 3 & 1 & 1 & 1 & 2 & 2 & 1 & 2 & 3 & 3 & & & & \\
\hline - nigrolimitatus & 2 & 1 & 3 & 3 & 1 & 4 & 3 & 4 & 1 & 1 & 3 & 1 & 1 & 2 & 3 & 2 & & & & 2 \\
\hline - pini & 5 & 1 & 3 & 3 & 1 & 1 & 3 & 2 & 2 & 2 & 1 & 2 & 1 & 2 & 3 & 3 & & & & \\
\hline - pseudopunctatus & 1 & 2 & 2 & 2 & 1 & 1 & 3 & 1 & 2 & 3 & 1 & 3 & 1 & 1 & 1 & 3 & & & & 2 \\
\hline - punctatus & 1 & 2 & 2 & 2 & 1 & 1 & 1 & 1 & 2 & 3 & 1 & 3 & 1 & 1 & 1 & 3 & & & 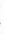 & 2 \\
\hline - rhamni & 1 & 2 & 2 & 2 & 1 & 1 & 3 & 1 & 1 & 2 & 1 & 3 & 1 & 2 & 3 & 3 & & & & \\
\hline - robustus & 5 & 2 & 1 & 1 & 1 & 1 & 1 & 1 & 2 & 3 & 1 & 3 & 1 & 1 & 1 & 3 & & & & 2 \\
\hline - torulosus & 5 & 2 & 3 & 2 & 1 & 1 & 3 & 1 & 1 & 1 & 2 & 2 & 1 & 1 & 2 & 1 & & & 3 & 2 \\
\hline - tremulae & 5 & 2 & 3 & 3 & 2 & 1 & 3 & 3 & 1 & 2 & 2 & 2 & 2 & 2 & 3 & 2 & & & & \\
\hline - trivialis & 5 & 2 & 3 & 3 & 2 & 4 & 2 & 3 & 1 & 1 & 2 & 2 & 2 & 2 & 3 & 3 & & & & 2 \\
\hline - tuberculosus & 4 & 2 & 3 & 2 & 3 & 1 & 3 & 3 & 1 & 2 & 2 & 2 & 1 & 2 & 3 & 3 & & & 3 & 2 \\
\hline - viticola & 2 & 2 & 2 & 2 & 1 & 4 & 3 & 1 & 1 & 1 & 3 & 1 & 1 & 2 & 2 & 1 & & & & 2 \\
\hline Phylloporia ribis & 3 & 2 & 4 & 3 & 1 & 1 & 1 & 1 & 2 & 1 & 2 & 2 & 2 & 1 & 3 & 3 & & & & 1 \\
\hline Onnia tomeniosa & 7 & 1 & 4 & 1 & 1 & 1 & 3 & 1 & 2 & 1 & 1 & 1 & 1 & 1 & 2 & 3 & & & & 1 \\
\hline - triquetra & 6 & 1 & 4 & 1 & 1 & 1 & 4 & 2 & 2 & 1 & 2 & 1 & 1 & 1 & 2 & 3 & & & 2 & 1 \\
\hline Inonotus cuticularis & 5 & 2 & 3 & 1 & 1 & 1 & 5 & 3 & 3 & 2 & 2 & 3 & 3 & 1 & 1 & 3 & & & & 1 \\
\hline - dryadeus & 5 & 2 & 3 & 1 & 1 & 1 & 4 & 2 & 2 & 3 & 1 & 3 & 1 & 1 & 1 & 3 & & & & 1 \\
\hline - dryophilus & 5 & 2 & 3 & 1 & 3 & 1 & 1 & 1 & 3 & 2 & 2 & 3 & 3 & 1 & 3 & 3 & & & & 1 \\
\hline - hispidus & 5 & 2 & 3 & 1 & 1 & 1 & 2 & 1 & 3 & 1 & 2 & 3 & 1 & 1 & 2 & 3 & & & & 1 \\
\hline - nidus-pici & 1 & 2 & 2 & 2 & 1 & 1 & 3 & 4 & 3 & 1 & 2 & 3 & 1 & 1 & 2 & 3 & & & & 1 \\
\hline - obliquus & 1 & 2 & 2 & 2 & 1 & 1 & 3 & 1 & 2 & 1 & 2 & 3 & 1 & 1 & 2 & 3 & & & & 1 \\
\hline - radiatus & 4 & 2 & 3 & 1 & 1 & 1 & 4 & 2 & 2 & 3 & 2 & 2 & 3 & 1 & 1 & 2 & & & & 1 \\
\hline - rheades & 4 & 2 & 4 & 1 & 3 & 1 & 1 & 1 & 3 & 2 & 2 & 3 & 3 & 1 & 3 & 3 & & & & 1 \\
\hline - tamaricis & 5 & 2 & 4 & 1 & 3 & 1 & 1 & 1 & 3 & 2 & 2 & 3 & 3 & 1 & 2 & 3 & & & & 1 \\
\hline Coltricia perennis & 7 & 4 & 3 & 1 & 1 & 1 & 1 & 1 & 3 & 3 & 2 & 3 & 1 & 1 & 1 & & & & & 1 \\
\hline Phaeolus schweinitzii & 6 & 3 & 3 & 1 & 1 & 5 & 1 & 1 & 2 & 1 & 1 & 2 & 4 & 3 & 2 & 3 & & & & 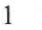 \\
\hline
\end{tabular}

Characters and character states: 1 Habit of the basidiocarp (1 resupinate, 3 effused, 5 dimidiate, 7 stipitate). 2 Host (1 gymnosperms only ... 4 angiosperms only). 3 Trichoderm, built up by anticlinal hyphae (1 lacking, 2 weak or variable incl. resupinate specimens, 3 well-developed, 4 at least as thick as the flesh, i.e., duplex). 4 Crust built up by periclinal hyphae aggregated by an amorphous secretion, appearing as a black line in section if overlain by a thick trichoderm (1 none or very weak, 2 average or variable incl. resupinate species, 3 well-developed). 5 Core in the basidiocarp ( 1 none, 2 variable, 3 well-developed). 6 Orientation of hyphae ( 1 parallel throughout, 2 parallel in the context but subinterwoven in the trama, 3 interwoven in the context but parallel in the trama, 4 interwoven in the context but subinterwoven in the trama, 5 interwoven throughout). 7 Hymenial setae (1 lacking, 2 rare or malformed, 3 moderately developed, 4 strongly developed and abundant, 5 slightly hooked, 6 strongly hooked). 8 Extrahymenial setae (1 lacking, 2 rare, 3 abundant, 4 extremely abundant, 5 giant, 6 tramal and giant setae occurring, 7 setoid skeletal hyphae). 9 Colour of the spore wall (1 hyaline, 2 faintly, 3 deeply yellow). 10 Staining of the spore wall ( 1 negative, 2 slightly cyanophilous, not dextrinoid, 3 strongly cyanophilous and dextrinoid). 11 Spore shape (1 globose [L/1@1.2], 2 oval, 3 allantoid $[\mathrm{L} / 1>2])$. 12 Spore size $(1$ small $[\mathrm{L}+1 \leqq 4 \mu \mathrm{m}], 2$ average, 3 large $[\mathrm{L}+1>6 \mu \mathrm{m}]) .13$ Type of mycelial culture (Fiasson \& David 1983). 14 Group according to the protein pattern (Fiasson \& Bernillon 1983). 15 Group according to the enzymatic activities (Fiasson \& Bernillon 1983). 16 Nuclear behaviour of the secondary mycelium (1 binucleate, 2 oligonucleate, 3 coenocytic). 17 Nature of the styrylpyrones in the basidiocarp (1 hispidin $+3,14^{\prime}$-bishispidinyl, 2 hispidin +hypholomin B + 3,14'-bishispidinyl, 3 hispidin + hypholomin B, 4 none, 5 hispidin alone). 18 Amount of styrylpyrones in the basidiocarp (1 large [hundreds of $\mu \mathrm{g}$ per $\mathrm{g}$, dry weight], 2 average, 3 low [some $\mu \mathrm{g} / \mathrm{g}$ ]). 19 Perenniality of the basidiocarp (1 annual, 2 perennial). 20 Honeycomb hymenium (1 no, 2 indistinct, 3 prominent network). 


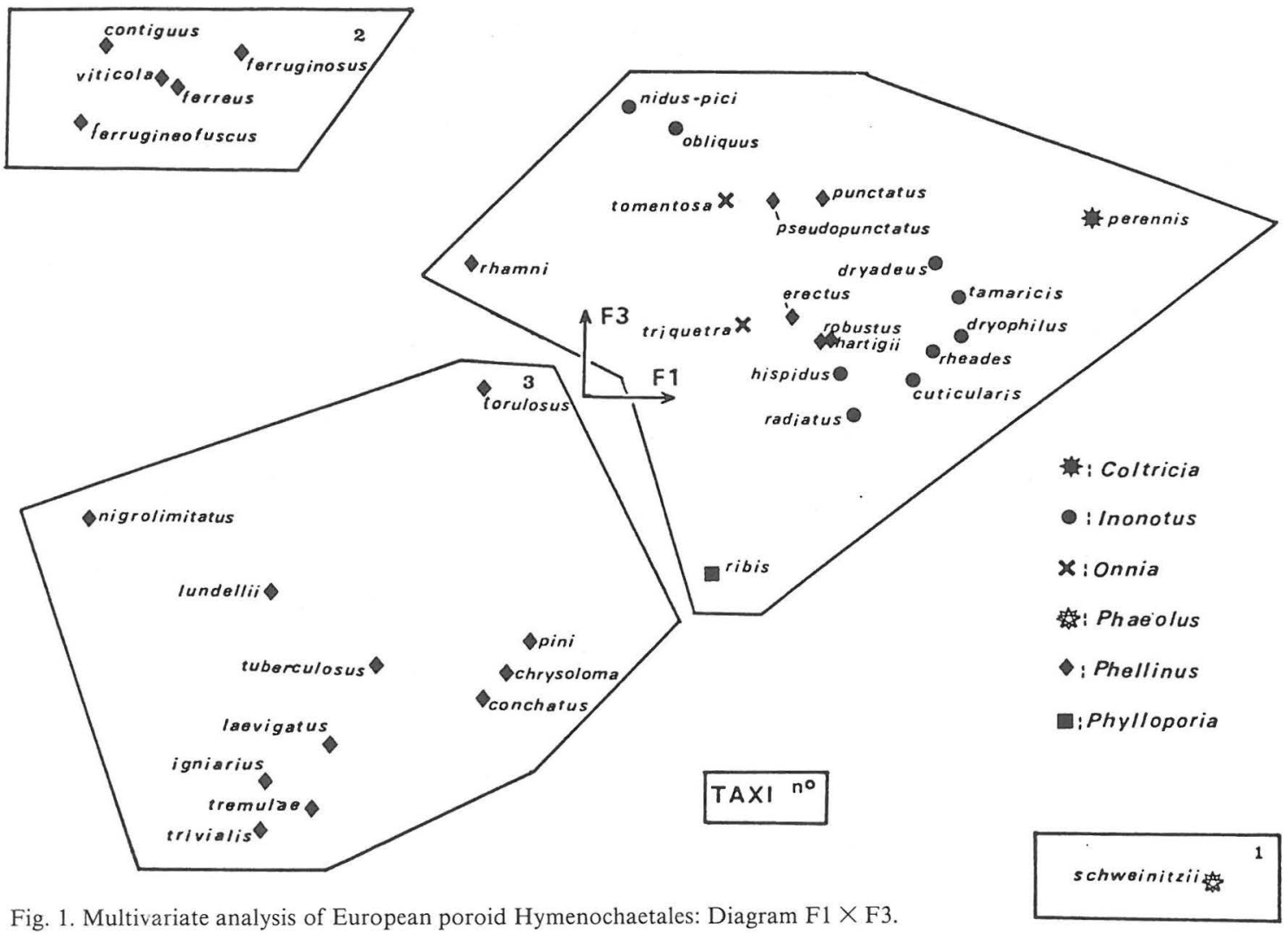

factors such as tradition and the convenience of determination keys. As the distributions of the characters we studied - botanical and biochemical - did not support the current generic concepts, and as the value of the miticity as a criterion within the Hymenochaetales is now questioned (Jahn 1981), it seemed interesting here to subject the whole of our results to a neutral numerical analysis. That taxometrics is the phenetist's tool does not preclude its use by other taxonomists (Wiley 1981): a phenogram can be an approximation of a cladogram (Génermont 1980).

Our study group seemed specially propitious, because it is a homogeneous and natural order. Here the choice of generic characters is rather easy and far from the somewhat caricatural conditions presented by Kendrick and Weresub (1966). It is well known that some similarities (e.g., the resupinate growth habit) represent convergence, but this possibility must be considered in most characters (spore wall pigmentation, hyphal construction, etc.). All in all, the fact that the characters receive no a priori weighting here need not be considered shocking.

\section{Mathematical tool}

An objective analysis, in which all the characters are taken equally into account, computes out the 'taxonomic-phenetic real distances' between the individuals, clusters them and extricates the more significant characters (Lebart et al. 1977). Each individual (species, in our case) is represented by a point in a space that has as many dimensions as the characters used. The whole sampling forms a 'cloud' and its principal axes (factors) are determined by the analysis. These main axes are the differences giving the best characterization. The analysis in turn reveals the position of each individual in relation to each factorial axis.

In practice, a plane representation generally visualizes most of the relationships between the analysed individuals. It is made up by the first two factorial axes $(\mathrm{F} 1 \times \mathrm{F} 2)$ as Cartesian coordinates. A certain amount of information, carried by the following factors, is then lost. Therefore such a twodimensional figure must be completed with the abscissae on F3, F4, etc, and/or with an automatic clustering process, such as TAXI. This regroups the individuals according to their positions on all significant factors. The TAXI process splits up the sampling progressively, not hierarchically, but taking all the characters into account.

As a drawing of the clusters on the two-dimensional diagram reflects only the first two factors, the groups obtained by TAXI may look very different. However, they are far more significant than those discernible on $\mathrm{F} 1 \times \mathrm{F} 2$. 


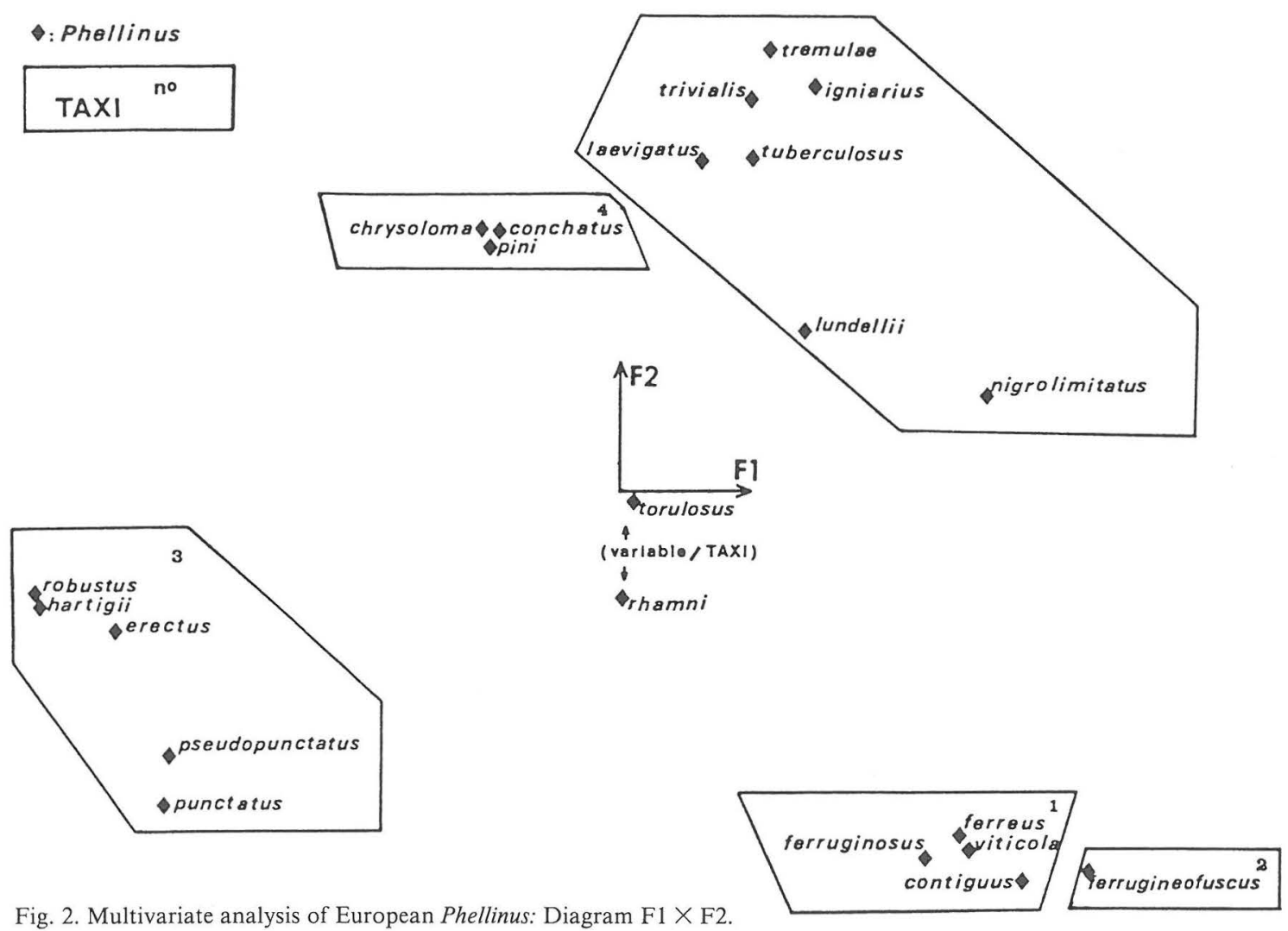

\section{Analysis of the poroid Hymenochaetales}

Some of the characters appear to be of negligible taxonomical weight and none are determinative. On F2, the isolation of $P$. schweinitzii and of the associated character states generally outweighs the other features. Apart from this, the more important characters turn out to be the colour of the spore print, the styrylpyrone patterns, the hyphal disposition within the context and dissepiments, the extrahymenial setae (though this may be partly an artifact, because of the number of character states, some appearing only once), and the structure of the cortical layers (artificially weighted by the partial coincidence of the 'medium' state with the resupinate habit). Then come the shape of the basidiocarp, spore size, and the type of culture.

Sharing no correlation with other characters, and so totally deprived of taxonomical significance are (at the level of the poroid Hymenochaetales as a whole) the host, the core of the basidiocarp and the amounts of styrylpyrone. The dimitic structure, which in classical keys isolates Phellinus, bears only moderate taxonomical significance (the same as the mere presence of hymenial setae!), for want of a high correlation with any other feature.

Figure 1 shows the distribution of 36 species of the F1 $\times$ F3 plane. F3 carries almost as much information as F2, on which distortion is caused by the extreme position of $P$. schweinitzii. At first glance, two things are evident: The isolation of Phaeolus and the discrimination of Phellinus (except mainly the $P$. robustus group). But the TAXI automatic classification based on the information of the first six factors leads to a very different conclusion. Here the first group to be isolated (after Phaeolus alone) is that of the resupinate Phellinus with small, allantoid spores: Fuscoporia (sensu Fiasson 1982) with the addition of $P$. ferrugineofuscus. $P$. nigrolimitatus accompanies them at first, then falls back to the next group. This means that, according to their overall phenotype, they differ more from the remainder of Phellinus than the latter from, e.g., Inonotus.

This leads to the same conclusion as the taxometric analysis of the botanical features of the basidiocarp (Fiasson \& David 1982): Phellinus shows phenetic diversity far larger than that of all the other undiscussed poroid Hymenochaetales put together. This casts doubts on its generic status. The question is not new to the polyporologists (Donk 1964), but the taxometric analysis indicates clearly which groups are to be separated and quantifies their relative degree of originality.

The analysis of Phellinus

The 24 representatives of Phellinus were submitted to a new analysis, which excluded characters $\mathbf{1 9}$ and $\mathbf{2 0 .}$ At this level, the more important characters are: size 
of the spore, nature of the upper layers (again, weighted somewhat artificially because of its partial coincidence with the shape of the basidiocarp), and staining and shape of the spore. Then come the API enzymatic pattern and the extrahymenial setae. The nature of the styrylpyrones, nuclear behaviour, orientation of the hyphae and colour of the spore wall also have some weight.

The distribution of the 24 species on the $\mathrm{F} 1 \times \mathrm{F} 2$ plane is shown in Fig. 2. The TAXI automatic classification corroborates the clustering apparent in the figure, and yields some interesting additional information: The first group to be isolated (level 2 classification) consists of Fuscoporia (as defined before) and $P$. ferrugineofuscus, but this latter segregates immediately afterwards (level 3 ). $P$. torulosus and $P$. rhamni are the only ambiguous species, though for very different reasons. $P$. torulosus appears to be undifferentiated, 'ancestral', as shown by its central position on all factorial planes; it combines features each of which elsewhere characterizes a different group. $P$. rhamni lacks the peculiar styrylpyrone pattern that anchors the other resupinate members of the $P$. igniarius complex, and therefore has some tendency to wander about.
Concluding remarks

The reader may wonder why we did not use the 'taxonomical distances' computerized between the species and between the clusters. First, their value is sensitive to the expression of data and calculation algorithms, and we lack the proficiency to choose those most appropriate to the problem in hand. Then, any calculator can give a result with six digits, but this is of no benefit if the initial data were accurate to one decimal place. Such apparent precision would be dangerously misleading with basic data as rough as are the morphological features, and probably often even the quantitative biochemical data of uncertain evolutionary value (Pasteur \& Pasteur 1980, Fiasson \& Bernillon 1983).

\section{The phylogenetic groundplan}

\section{Principles}

Wagner's classical method of groundplan divergence analysis proceeds in the following manner (Wiley 1981):

1) Determine which of the character states in a series of character transformations is the apomorphic one, i.e., derived, advanced, etc.

Table 2. Wagner divergence analysis of 36 European poroid Hymenochaetales, using 20 transformation series. Each character of Table 1 (No. 2 Host omitted) is treated as a transformation series, coded from 0 (plesiomorphy) to 1 (apomorphy), the numbering of the column being unchanged. DI is for total divergence index of the species.

Transformation series

\begin{tabular}{|c|c|c|c|c|c|c|c|c|c|c|c|c|c|c|c|c|c|c|c|}
\hline 1 & 3 & 4 & 5 & 6 & 7 & 8 & 9 & 1 & 11 & 12 & 13 & 14 & 15 & 16 & & 18 & 19 & 20 & DI \\
\hline 0.6 & 0 & 1 & 0 & 0 & 0 & 0.2 & 0 & 0.5 & 1 & 0 & 0 & 1 & 1 & 1 & 0 & 0 & 1 & 1 & 8.3 \\
\hline 0.6 & 0 & 1 & 0 & 0.25 & 0 & 0.2 & 0 & 0.5 & 1 & 0 & 0 & 1 & 1 & 10 & 0.5 & 0.5 & 1 & 1 & 9.55 \\
\hline 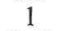 & 0.5 & 0.5 & 0 & 1 & 0 & 0.75 & 1 & 0 & 1 & 1 & 0 & 1 & 0 & 0 & 0.5 & 1 & 1 & 1 & 11.25 \\
\hline 0.45 & 1 & 0 & 0 & 0 & 0 & 0 & 0 & 1 & 1 & 1 & 0 & 0 & 1 & 1 & 0.5 & 0.5 & 1 & 1 & 9.45 \\
\hline 1 & 0.5 & 0.5 & 0 & 1 & 0 & 0 & 1 & 0 & 1 & 1 & 0 & 1 & 0 & 0 & 0.5 & 1 & 1 & 1 & 10.5 \\
\hline 1 & 0.5 & 0.5 & 0 & 0.75 & 1 & 1 & 1 & 0 & 1 & 1 & 0 & 1 & 0 & 0.5 & 0.5 & 1 & 1 & 1 & 12.75 \\
\hline 1 & 0.5 & 0.5 & 0 & 1 & 0.5 & 0.6 & 1 & 0 & 0 & 1 & 0 & 1 & 1 & 0 & 0.5 & 1 & 1 & $\hat{1}$ & 11.6 \\
\hline 0.3 & 1 & 0 & 0 & 0 & 0.5 & 0 & 0 & 1 & 1 & 1 & 0 & 0 & 1 & 1 & 0 & 0.5 & 1 & 1 & 9.3 \\
\hline 0.45 & 0 & 1 & 1 & 1 & 0 & 0.3 & 1 & 0 & 0 & 0 & 1 & 1 & 1 & 1 & 0.5 & 0.5 & 1 & 1 & 11.75 \\
\hline .75 & 0 & 1 & 0 & 0 & 0 & 0 & 1 & 0.5 & 0 & 0 & 1 & 1 & 1 & 1 & 0.5 & 0.5 & 1 & 1 & 10.25 \\
\hline .75 & 0 & 1 & 0 & 1 & 0 & 0 & 1 & 0 & 0 & 0 & 0 & 1 & 1 & 1 & 0.5 & 1 & 1 & 1 & 10.25 \\
\hline 0.75 & 0 & 1 & 0 & 1 & 0 & 0.4 & 1 & 0 & 1 & 1 & 0 & 1 & 1 & 0.5 & 0.5 & 0 & 1 & 1 & 11.15 \\
\hline 0.3 & 0 & 1 & 0 & 0 & 0 & 0.2 & 0 & 0.5 & 1 & 0 & 0 & 1 & 1 & 1 & 0 & 0 & 1 & 1 & 8 \\
\hline 1 & 0.5 & 0.5 & 0 & 0 & 0 & 0 & 0 & 1 & 1 & 1 & 0 & 0 & 1 & 1 & 0.5 & 1 & 1 & 1 & 10.5 \\
\hline 1 & 0.5 & 0.5 & 0 & 0 & 1 & 0 & 0 & 1 & 1 & 1 & 0 & 0 & 1 & 1 & 0.5 & 1 & 1 & 1 & 11.5 \\
\hline 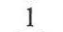 & 0.5 & 0.5 & 0 & 0 & 0 & 0 & 1 & 0.5 & 1 & 1 & 0 & 1 & & 1 & 1 & 1 & 1 & 1 & 12.5 \\
\hline 0.3 & 1 & 0 & 0 & 0 & 0.5 & 0 & 0 & 1 & 1 & 1 & 0 & 0 & 1 & 1 & 0 & 0.5 & 1 & 1 & 9.3 \\
\hline 0.3 & 0 & 0.5 & 0 & 0 & 0 & 0 & 1 & 0 & 0 & 0 & 0 & 0 & 0 & 0 & 0 & 0 & 1 & 1 & 3.8 \\
\hline 0.3 & 0 & 1 & 1 & 0 & 0 & 0.3 & 4 & 0.5 & 0 & 0 & 1 & 1 & 1 & 0.5 & 0.5 & 0.5 & 1 & 1 & 10.6 \\
\hline 0.3 & 0 & 1 & 0.5 & 1 & 0.5 & 0.3 & 1 & 0 & 0 & 0 & 1 & 1 & 1 & 1 & 0.5 & 0.5 & 1 & 1 & 11.6 \\
\hline 0.45 & 0 & 0.5 & 1 & 0 & 0 & 0.3 & 1 & 0.5 & 0 & 0 & 0 & 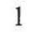 & 1 & 1 & 0.5 & 0 & 1 & 1 & 9.25 \\
\hline 1 & 0.5 & 0.5 & 0 & 1 & 0 & 0 & 1 & 0 & 1 & 1 & 0 & 1 & 0 & 0 & 0.5 & 1 & 1 & 1 & 10.5 \\
\hline 0.6 & 0.5 & 1 & 0 & 0 & 1 & 0 & 0 & 0 & 0 & 0 & 1 & 0 & 1 & 1 & 0.5 & 0.5 & 0 & 0.5 & 7.6 \\
\hline 0 & 0.5 & 0 & 0 & 0 & 0 & 0 & & 0 & 1 & & U & 0 & 0 & 1 & 0.5 & 1 & 0 & 1 & 6 \\
\hline 0.15 & 0.5 & 0 & 0 & 0 & 0.5 & 0.2 & 0 & 0 & 0 & 1 & 0 & 0 & 0 & 1 & 0.5 & 0.5 & 0 & 1 & 5.35 \\
\hline 3 & 0 & 0 & 0 & 0 & 0.5 & 0.3 & 1 & 0.5 & 0 & 1 & 1 & 0 & 1 & 1 & 1 & 1 & 0 & 0.5 & 9.1 \\
\hline 0.3 & 0 & 0 & 0 & 0 & 0.5 & 0.2 & 0 & 1 & 1 & 1 & 0 & 0 & 1 & 1 & 1 & 1 & 0 & 0.5 & 8.5 \\
\hline 0.3 & 0 & 0 & 1 & 0 & 1 & 0 & 1 & 0.5 & 0 & 1 & 1 & 0 & 1 & 1 & 0.5 & 1 & 0 & 0.5 & 9.8 \\
\hline 0.3 & 0 & 0 & 0 & 0 & 0.5 & 0 & 1 & 0 & 0 & 1 & 0 & 0 & 0 & 1 & 0 & 0 & 0 & 0.5 & 4.3 \\
\hline 1 & 0.5 & 0.5 & 0 & 0 & 0 & 0.4 & & 0 & 0 & 1 & 0 & 0 & 0 & 1 & 0.5 & 1 & 0 & 0.5 & 7.4 \\
\hline 1 & 0.5 & 0.5 & 0 & 0 & 0 & 0 & 0 & 0 & 0 & 1 & 0 & 0 & 0 & 1 & 1 & 1 & 0 & 0.5 & 6.5 \\
\hline 0.45 & 0 & 0 & 0 & 0 & 0.5 & 0.2 & 0 & 1 & 0 & 0 & 1 & 0 & 1 & 0.5 & 0.5 & 0 & 0 & 0.5 & 5.65 \\
\hline 0.4 & 0.5 & 0 & 1 & 0 & 1 & 0 & 1 & 0.5 & 0 & & 1 & 0 & 1 & 1 & 0.5 & 1 & 0 & 0.5 & 10.45 \\
\hline 0.45 & 0.5 & 0 & 1 & 0 & 1 & 0 & & 0.5 & 0 & 1 & 1 & 0 & 0 & 1 & 0.5 & 1 & 0 & 0.5 & 9.45 \\
\hline U & 0 & 0 & 0 & 0 & 1 & 0 & 1 & 1 & 0 & 1 & 0 & 0 & 1 & 1 & 1 & 1 & 0 & 0 & 8 \\
\hline 0.15 & 0 & 0 & 0 & 0.5 & 1 & 0 & 0 & 0 & 1 & 0 & 1 & 1 & 0 & 1 & 1 & 0 & 0 & 0 & 6.65 \\
\hline
\end{tabular}

Phellinus chrysoloma

- conchatus

- contiguus

- erectus

- ferreus

- ferrugineofuscus

- ferruginosus

- hartigii

- igniarius

- laevigatus

- lundellii

- nigrolimitatus

- pini

- pseudopunctatus

- punctatus

- rhamni

- robustus

- torulosus

- tremulae

- trivialis

- tuberculosus

- viticola

Phylloporia ribis

Onnia tomentosa

- triquetra

Inonotus cuticularis

- dryadeus

- dryophilus

- hispidus

- nidus-pici

- obliquus

- radiatus

- rheades

- tamaricis

Coltricia perennis

Phaeolus schweinitzii 
2) Assign to the plesiomorphic (primitive, ancestral, etc.) character state in each transformation series the score of 0 , and to each apomorphic state the score of 1 . If more than two homologues are present, the 'intermediate apomorphies' are scaled between 0 and 1.

3) Construct a table of the taxa and the coded characters. This has been done in Table 2 from the data of Table 1, excluding the host.

4) Determine the divergence, by totalling the values for each taxon from the whole transformation series. This is the total divergence index (DI) in Table 2.

j) Plot the taxa on a graph, by placing each taxon on one of a number of concentric semi-circles. The radius of a taxon equals its divergence index.

6) The lines connecting the taxa are determined by the shared synapomorphies. Ancestral species (indicated by open circles) of progressively higher levels are reconstructed step-by-step from the shared synapomorphies and symplesiomorphies of their supposed descendants.

\section{Poroid Hymenochaetales:}

Coded character data matrix

Table 2 shows the experimental data of Table 1 translated into steps of a transformation series, one for each character. Assessing what is the plesiomorphic (primitive, ancestral, archaic) character state and what is the apomorphic (derived, advanced) one was in some cases straightforward and in others required some subjective 'guesswork' with distribution within the poroid Hymenochaetales and also in outgroups (Hymenochaete, Polyporaceae) as background evidence.

For the shape of the basidiocarp, we considered the pileate habit to be primitive and the resupinate derived. A primitive saprophytic fungus at ground level has to be pileate to have its hymenial layer facing downward, as is generally the case among the Homobasidiomycetes. It remains so when evolving toward mycorrhizal symbiosis. When turning to parasitism and 'climbing up' its host, it becomes dimidiate when on the side of the trunk or main branches, then ultimately resupinate when under the twigs (Donk 1971). As a group, the Hymenochaetales are an advanced taxon. Their common ancestor should not be envisaged as a mycelial mat, but as a lignicolous fungus with an already well-differentiated basidiocarp. The possibility of parallel evolution was not taken into account here, though one may perhaps consider it for the dimidiate Inonotus, the basidiocarp of which is simpler in construction than that of Phellinus.

Owing to their distribution, the differentiated trichoderm and crust are considered primitive and derived, respectively. The core of some dimidiate species was treated as an apomorphy, while the lack of it in the resupinate members of the $P$. igniarius complex would theoretically have to be scored as surevolution.

Of the other characters, the more widespread character state (for the hyphal orientation and the setae), or the less differentiated character (for spore features and the mycelial characters, except the nuclear behaviour) are considered plesiomorphic.

In the nuclear behaviour progress is assumed to have been from binucleate to coenocytic.

The distribution of the styrylpyrones strongly suggests that, within the poroid Hymenochaetales, the primitive character state is the co-occurrence of hispidin and its two dimers (3,14'-bishispidinyl and hypholomin B) and the ultimate state was considered to be total loss of extractable styrylpyrones. Quantitatively, as evolution worked towards reduction of extractable styrylpyrones, richness was seen as primitive.

Perenniality, strongly correlated with dimiticity, was seen as apomorphic. Lack of definite evidence forbade us to differentiate perenniality from miticity in order to distinguish primitive from reappeared monomiticity. The difficulties of using miticity as a criterion are much more evident now than when it was raised to the rank of generic criterion (Jahn 1981, Fiasson \& David 1983).

In the configuration of the interbasidial secretion, best seen in front view, progress is suggested to have been towards a distinct honeycomb structure (Niemelä 1975).

\section{Poroid Hymenochaetales: A groundplan}

Figure 3 shows the phylogenetic diagram obtained from the criteria described above. Some comments are needed: First, as most divergence indices are not whole numbers, the traditional concentric semicircles representing the degrees of anagenetic divergence were omitted. Second, the figure is not a normal phylogenetic groundplan, i.e., the projection of a phylogenic tree on the 'Present' plane. The sampling being limited to Europe, it is a projection of the extremities of the branches nowadays represented in Europe, with their past insertion extrapolated. Therefore artificial precision was avoided, trichotomies were not resolved into successive dichotomies, and the present-day species were not excluded from ancestral nodes. Reciprocally, when an ancestral species is plotted very close to an extant one, this may well reflect anagenesis rather than speciation.

The cladogram has been built up centripetally and is therefore easier to read from the centre outwards. The first dichotomy is between the genera without a neat interbasidial network (Phaeolus, Coltricia) and those with a more or less distinct honeycomb structure in their hymenium (Inonotus, Phylloporia, Phellinus, Onnia). This corresponds to the distinction between the proposed suborders Phaeolinae and Hymenochaetinae (the tribes Phaeolae and Phellinae as defined by Fiasson 1982: 25). This receives remarkable support from the septal ultrastructure, which was not taken into account in our data matrix, and of which we were unaware when proposing the two tribes in 1982. C. perennis and P. schweinitzii have normal perforate parenthesomes, while at least the type species of Inonotus, Phellinus and Onnia have nonperforate ones, generally associated with the Heterobasidiomycetes (Moore 1980). Now it has turned out that Asterodon also belongs to the nonperforate parenthesome type (Moore, in litt. 1983). 
Karstenia 24. 1984

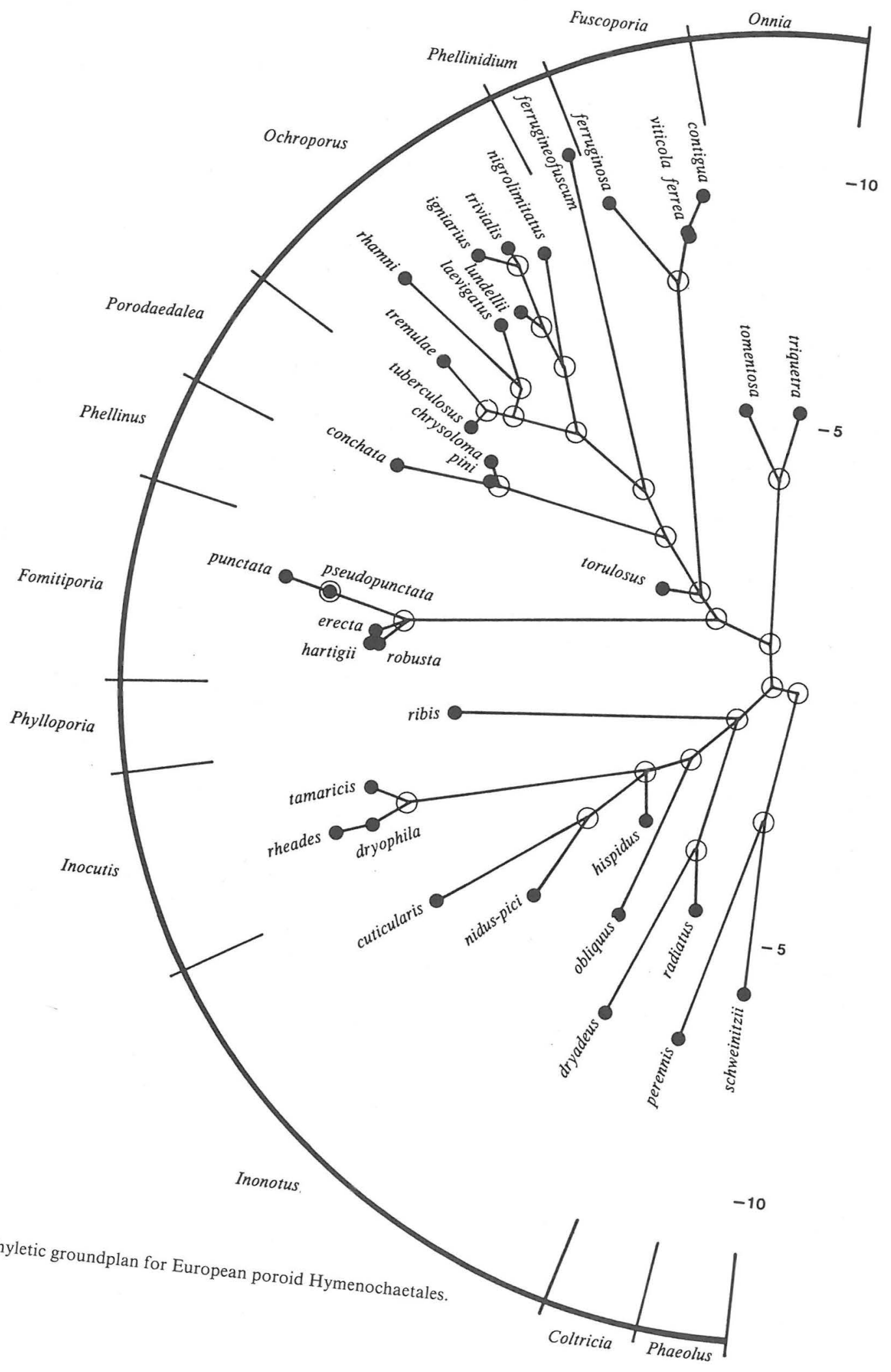

Fig. 3. Wagner phyletic groundplan for European poroid Hymenochaetales. 
More evidence is needed, however, before further conclusions are made.

Among the Hymenochaetinae, the next dichotomy is between the genera with blurred interbasidial networks (Inonotus, Phylloporia) and those with a neat honeycomb hymenium (Phellinus, Onnia), a division strongly correlated with different hyphal systems. In Inonotus, the best isolated group is $I$. rheades and its allies (Inonotus sect. Phymatopilus Donk) and for this reason we propose its separation in a new genus.

In Phellinus, the first group to emerge is that of $P$. robustus (Phellinus subg. Cyanovosporus Fiasson). This is mostly due to the difference we found between its covering layers and those of the rest of Phellinus. Besides, the hyphae intermediary between generative and skeletal are especially conspicuous here (Jahn 1981), and so this group is 'the least Phellinus-like within Phellinus'. The next group segregated in Phellinus is Fuscoporia (sensu Fiasson 1982), which has retained the binucleate state though many of its other characters are advanced. The group of $P$. pini is more closely related to $P$. torulosus than it appears, if the loss of the binucleate state did not occur as a separate step, but during the passage from $P$. 'pretorulosus' (or $P$. torulosus itself) to $P$. pini. The remainder of Phellinus (Ochroporus sensu Fiasson 1982 and Phellinidium) is characterized by the occurrence of 3,14'-bishispidinyl without hypholomin B. Ochroporus itself is dichotomized according to two congruent characters: hyphal orientation in the basidiocarp (Cunningham 1965, Niemelä 1972) and colourability of the spore wall (Fiasson \& David 1983).

\section{Conclusion}

As mentioned earlier, we consider that the most reliable results are those for which agreement exists between the two approaches - phenetic and phylogenetic. Both approaches show:

1) Relative isolation of Phaeolus schweinitzii.

2) Clustering of the species in Inonotus and especially Phellinus into infrageneric entities that appear natural - perhaps even more so that the large genera themselves.

These points have been familiar to mycologists for a long time, but they are defined and demonstrated more clearly here. They form the basis for all the following conclusions.

\section{The major division of the Hymenochaetales}

Although $P$. schweinitzii shares many features with Coltricia, some mycologists exclude it from the Hymenochaetales, mainly because it produces brown-rot (Parmasto \& Parmasto 1979). As we discussed earlier (Fiasson 1982), even from the viewpoint of the wood-decaying metabolism, $P$. schweinitzii is not far from typical Hymenochaetales. In any case its styrylpyrone production is a very strong argument in favour of its inclusion in this order. As its pigmentary metabolism also shows peculiarities separating it from the Inonotus-Phellinus group, we propose its separation in a suborder of its own.
If the non-poroid Hymenochaetales are also taken into account, the rest of the order (apart from the Phaeolus group) shows two groups of taxa. Hymenochaete and the other non-poroid taxa are characterized by the ability to accumulate hispidin and sometimes leucohymenoquinone, but neither hypholomin B, nor 3,14'-bishispidinyl. The other group is the poroid one: these taxa can accumulate hispidin, hypholomin B and/or 3,14'-bishispidinyl, but not leucohymenoquinone, and their hymenium shows a more or less distinct honeycomb structure. As seen already here, the last group is the most heterogeneous.

When deciding the major division of the order, we first intended to separate three main groups, as defined above. This, however, would not emphasize sufficiently the originality of the Phaeolus group, and besides the last group would be much more heterogeneous than the others. On the other hand, we wished to achieve a simple system in preference to a complicated hierarchy. As a compromise between these partly opposite requirements, we propose the following division of the hymenochaetaceous fungi:

Order Hymenochaetales Oberwinkler

Suborder Hymenochaetinae Fiasson \& Niemelä

Fam. Hymenochaetaceae Donk (genera Hymenochaete Lév., Asterodon Pat., Hydnochaete Bres.)

Fam. Inonotaceae Fiasson \& Niemelä (genera Inocutis Fiasson \& Niemelä, Inonotus Karst., Phylloporia Murr.) Fam. Phellinaceae Jülich (genera Phellinus Quél., Fomitiporia Murr., ?Fulvifomes Murr., Fuscoporia Murr., ?Inonotopsis Parm., Ochroporus J.Schroet., Onnia Karst., Phellinidium Kotl., Porodaedalea Murr.) Suborder Phaeolinae Fiasson \& Niemelä

Fam. Phaeolaceae Jülich (genera Phaeolus Pat, Coltricia S.F. Gray)

Hymenochaetales Oberw. 1977 emend. Fiasson \& Niemelä (Oberwinkler 1977: 89): Homobasidiomycetes with poroid, smooth or spiny hymenophore; hyphae golden to brown, xanthochroic and consistently simple-septate (in addition, hyaline simple-septate hyphae may occur); setae present in most species; parenthesomes nonperforate in most species; capable of synthetizing styrylpyrones; producing white-rot or seldom imperfect brown-rot. Typus: Hymenochaetaceae Donk. - These fungi do not manifest true dimiticity at all: the coloured hyphae, present in all the species, are septate and therefore cannot be regarded as skeletal hyphae proper; intermediaries are also common. The presence of the styrylpyrones could not be confirmed in Asterodon, but the nonperforate parenthesomes, presence of setae, hyphal characters, etc. support its inclusion. By the 'imperfect brown-rot' we mean Phaeolus, which does not react to some tests as a true brown-rot fungus (Gilbertson et al. 1975), and whose basidiocarp has the triterpene content of a white-rot species (Yokoyama et al. 1975).

Hymenochaetinae Fiasson \& Niemelä, subordo nov. Hymenochaetales hymenophoro poroso, glabro vel spinoso; setae in speciebus plurimis adsunt; parenthesomata non-perforata. Hispidinum et unun vel plura ex sequentibus procreant: leucohymenoquinonum, hypholominum B, 3,14'-bishispidinylum. Cariem albam producunt. Hymenochaetales with poroid, smooth or 
spiny hymenophore; setae present in most species; parenthesomes nonperforate; synthetizing hispidin and one or more of the following: leucohymenoquinone, hypholomin B, 3,14'-bishispidinyl; producing white-rot. Typus: Hymenochaetaceae Donk. - This suborder is best understood, when contrasted with Phaeolinae. The presence of setae and the lack of perforation in the parenthesomes are diagnostic of this suborder. The morphology varies greatly, and the first family (containing the non-poroid taxa) differs distinctly from the other two.

Hymenochaetaceae Donk 1948 emend. Fiasson \& Niemelä (Donk 1948: 474): Hymenochaetinae with smooth or spiny hymenophore; hymenium not forming a honeycomb structure; setae present; accumulates hispidin and leucohymenoquinine, but neither hypholomin B nor 3,14'-bishispidinyl. Typus: Hymenochaete Lév. - This family and its accurate delimitation fall outside the scope of the present study. Hydnochaete Bres. most probably belongs here (cf. Ryvarden 1982). The inclusion of Asterodon Pat. is provisional. This group particularly needs a more thorough study with extra-European material.

Inonotaceae Fiasson \& Niemelä, fam. nov. Hymenochaetinae hymenophoro poroso; sporocarpia reflexa vel resupinata; annuae vel raro imperfecte perennes; structura hypharum monomitica; setae adsunt vel nullae; sporae ellipsoideae, dextrinoideae, valde cyanophilae; reticulum faveolatum hymenii indistinctum. Hymenochaetinae with porous hymenophore; fruit bodies bracket-shaped or resupinate; annual or seldom imperfectly perennial; hyphal structure monomitic; setae present or absent; spores ellipsoid, dextrinoid and strongly cyanophilous; honeycomb structure in hymenium indistinct. Typus: Inonotus Karst. - The species can accumulate hispidin, hypoholomin B and/or 3,14'-bishispidinyl, but not leucohymenoquinone. The spore characters are good for separating this family from the following, and so is the monomitic hyphal system. Most species are distinctly annual: Phylloporia ribis is perennial, or rather reviving because old parts of its sporocarps start to disintegrate after one or two winters. The taxonomy of the genus Phylloporia Murr. needs closer study. Phymatopilus of Donk (1974, as sect.) was erected as a genus (Inocutis) because it was most clearly separated from the rest of Inonotus. The remainder is a heterogeneous group; more knowledge of the extra-European species is needed before proposals for further division can be made.

Phellinaceae Jül. 1981 emend. Fiasson \& Niemelä (Jülich 1981: 384): Hymenochaetinae with porous hymenophore; fruit bodies stipitate, bracket-shaped or resupinate; perennial or seldom annual; hyphal system dimitic in appearance, with thin-walled hyaline hyphae besides the pigmented ones; setae mostly present; honeycomb structure in hymenium distinct. Typus: Phellinus Quél. - The species of this family can accumulate hispidin, hypholomin B and/or 3,14'-bishispidinyl, but not leucohymenoquinone. The spore characters vary greatly among the genera; the best character differentiating this family from the Inonotaceae is the distinct honeycomb struc- ture, with the basidia and basidioles cohering in one network. Perenniality, when present, is strongly indicative of this family. The dimitic appearance is mostly clear, but remains vague in Fomitiporia, and even more so in Phellinidium and Onnia. The inclusion of Inonotopsis Parm. is provisional; see the discussion of Niemelä \& Kotiranta (1983). The generic division will be presented in a separate section. Apart from its name, the family in our sense has little in common with that of Jülich (1981).

Phaeolinae Fiasson \& Niemelä, subordo nov. Hymenochaetales hymenophoro poroso; setae nullae; parenthesomata perforata; hispidinum procreant, nullum autem ex sequentibus: leucohymenoquinonum, hypholominum B, 3,14'-bishispidinylum; cariem albam vel cariem brunneam imperfectam producunt. Hymenochaetales with poroid hymenophore; setae absent; parenthesomes perforate; synthetizing hispidin but none of the following: leucohymenoquinone, hypholomin B, 3,14'-bishispidinyl; producing white-rot or imperfect brown-rot. Typus: Phaeolaceae Jülich. The perforation of the parenthesomes is the greatest difference from the Hymenochaetinae. The constancy of the lack of setae needs further investigation in Coltricia.

Phaeolaceae Jül. emend. Fiasson \& Niemelä (Jülich 1981: 348): Phaeolinae with porous hymenophore; fruit bodies with tendency to stipitate habit; annual; monomitic; no honeycomb structure in hymenium. Typus: Phaeolus Pat. - Here again, the name of the family is adopted from Jülich, but not the concept: he also included the genus Pycnoporellus Murr., which is a very distant taxon (Fiasson 1982), better placed in the vicinity of Laetiporus Murr. (Niemelä 1980). Coltricia is included in the family by us; Jülich kept it in the vicinity of Onnia, Inonotus, etc.

\section{Notes on Inonotus and Phellinus}

The only character in the data matrix that seems to support the current generic distinction between Inonotus and Phellinus is the hyphal system (actually isolates Phellinus from all other genera). The other characters cut across the genera or isolate smaller entities within them. Four such groupings appear at first glance. Within Inonotus, the group of $I$. rheades emerges, which has a core and a characteristic chromatogram (Fiasson 1982). In Phellinus, the three clearest groups are that of $P$. robustus (with globose, cyanophilous and dextrinoid spores), that of $P$. igniarius (with a characteristic styrylpyrone pattern) and that of $P$. ferreus (mainly resupinate species with generally small, allantoid spores and binucleate secondary mycelium).

But what rank do these entities deserve? The first clusters isolated in TAXI analysis are the most 'original' judged on purely phenetic criteria. Here at least the $P$. robustus and $P$. ferreus groups seem to deserve generic ranking, rather than Phellinus as a whole. The phylogenetic approach is less straightforward, less automatic. Some of the well-defined genera may be monospecific while others embody a very large number of species, so that it is impossible to lay down a rule-of-thumb about how many dicho- 
tomies above the extant species are needed to make up a genus.

In Fig. 3 we drew both Inonotus and Phellinus as monophyletic. The limited data at hand did not justify any other treatment. However, this does not imply that they are good genera: any natural taxon, regardless of its rank in the hierarchy, is monophyletic. Phylogenetically, a genus can be recognized in a well-defined branch arising not far above the the (sub)tribal level: Then, by analogy with Onnia, Phellinus appears to deserve to be kept as a genus as well. From a less theoretical viewpoint, if the number of species and the importance of the hiatuses between the groups are considered, each of the lines (i.e., the sectors in Fig. 3) within Phellinus should be accorded generic rank. As mentioned above, our groundplan should not be considered absolutely exact; in fact we have a tetramerous division of a hypothetical ancestor very close to extant $P$. torulosus, leading to the groups of $P$. robustus, $P$. igniarius (from which the group of $P$. ferrugineofuscus may be further separated), $P$. ferreus and $P$. pini. Accordingly, we previously suggested for the first three groups the subgeneric names Cyanovosporus, Ochroporus and Fuscoporia, respectively (Fiasson 1982, Fiasson \& David 1983). Being rather poorly differentiated, $P$. torulosus is situated somewhere in between the groups of $P$. pini and $P$. ferreus. We first connected it with the $P$. pini complex, but new observations (especially the presence of the crystal hyphae) also reveal affinities with the latter group. After repeated consideration, we find that the only solution is to separate $P$. torulosus from both complexes. This point is important, because $P$. torulosus is the type of the genus Phellinus, and so determines the future destiny of the name.

Singer (1975) states that a serious attempt at reorganisation on the generic level requires a thorough knowledge of the world flora. In practice, this demand is often exorbitant and would postpone such revisions until a very distant future. Of course, the wider the material, the more reliable the results. Actually, for the various characters used here, we studied more than a hundred tropical collections and our observations will be published as soon as the botanical determinations of the specimens have been confirmed. However limited these studies may be, they nevertheless allow us to be sure that a profound knowledge of Phellinus at global level will not seriously alter the concepts of the groups distinguished by us in the European collections. For instance, we never encountered a specimen combining the styrylpyrones of Ochroporus and the spores of Fomitiporia (Cyanovosporus). The extra-European material will rather make it possible to recognize other groups in the remainder of Phellinus.

Taking all these matters into account, we propose the recognition of the following genera within the fungi earlier included in Inonotus and Phellinus. In the difficult questions of the generic typification, we followed Donk (1960, 1962).
Inonotus Karst. 1879. Type: Polyporus hispidus Bull.: Fr. - For details of the nomenclature, typification and possible future division, see Donk (1974). In the present sense this is still a heterogeneous genus.

Inocutis Fiasson \& Niemelä, gen.nov. Sporocarpium medulla marmorata praeditum, hymenium sine setis. Sporocarp with marmorate core, hymenium without setae. Type: Polyporus rheades Pers. 1825. -This is the Inonotus rheades complex, discussed earlier, or Inonotus sect. Phymatopilus Donk (Donk 1974: 228). We changed the name proposed by Donk to a shorter one that accords with the old genus. Meaning a fibrous cutis, it fits the European species well.

Phylloporia Murr. 1904. Type: Phylloporia parasitica Murr. - We have adopted this genus in the sense of Ryvarden (1978), containing $P$. ribis (Schum.: Fr.) Ryvarden as the only European representative. The type of the genus, $P$. parasitica, is epiphyllous, and therefore very different from the other species included by Ryvarden (1978) and Ryvarden \& Johansen (1980: four pileate, epixylous, tropical species). We have not studied the type, but the evidence given by Ryvarden points to a homogeneous genus. Jahn (1981) casts some doubts on this solution. If $P$. ribis is to be separated from Phylloporia, an available genus is Cryptoderma Imaz. 1943, with $P$. ribis as the type.

Fomitiporia Murr. 1907. Type: Fomitiporia langloisii Murr. = Phellinus punctatus (Karst.) Pilát. - Generally known as the 'Phellinus robustus complex' this is Phellinus subg. Cyanovosporus Fiasson (Fiasson 1983: 29). The genus is very well-defined, characterized by subglobose, strongly cyanophilous, dextrinoid spores; the context is brass-coloured, composed of hyphae which show very weak differentiation into the so-called skeletal and generative hyphae: hymenial setae do exist in most species, but are remarkably often very rare; in addition, the hymenium often possesses ampullaceous cystidioles. Of the groups of the traditional Phellinus, this is closest to Inonotus.

Porodaedalea Murr. 1905. Type: Boletus pini Brot. $1804=$ Daedalea pini Brot.: Fries $1821=$ Phellinus pini (Brot.) A. Ames. - The Phellinus pini complex. The spores are ellipsoid and rather thick-walled; they are not dextrinoid, but do possess moderate cyanophily. The reaction is not strong, and therefore depends on the quality of the dye. A positive reaction can be seen, for example, using the water-soluble aniline blue of Merck (Art. 1275), prepared according to Singer (1975: 94). The genus is further characterized by the pileus surface, which is pubescent or hirsute at first, later developing a rather weakly defined crust. The pores are round to labyrinthine, and without crystal hyphae in their mouths. Ungerminated spores often remain in old tubes, blocked by secondary mycelium: they swell and absorb brown pigments from the hyphae and are sometimes reported as chlamydospores (Ryvarden 1978). The hymenium possesses subulate setae, and in most species setae can also be found embedded in the tube walls. 
Ochroporus J.Schroet. 1888. Type: Polyporus igniarius L.: Fr. - Ochroporus comprises the $P$. igniarius complex, as outlined by Niemelä (1972, 1974,1975 , 1977). The brown and thick-walled hyphae are well distinguished from the hyaline and thin-walled ones, and so the species are usually regarded as dimitic. The hymenium shows a very well-developed honeycomb structure plus subulate setae. A rudimentary core is present in many of the pileate species. Apart from the hymenial and core setae, setal elements are absent, as are also crystal hyphae. The spores are rather thick-walled and indextrinoid; the cyanophily is as in Porodaedalea. The sporocarps are not hirsute but develop a regular crust. No chlamydospore-like spores remain in old tubes.

Phellinidium (Kotl.) Fiasson \& Niemelä, stat.nov. Basionym: Phellinus subg. Phellinidium Kotl. (Kotlaba 1968: 29). Type: Poria ferrugineofusca Karst. 1887. - Kotlaba (1968) defined this group very well, and we need only repeat the main characters. The most striking are the macrosetae (also called the setoid skeletal hyphae) which predominate in both the trama and the context, overshadowing the true hyphae. The latter are very weakly differentiated. The spores are thin-walled, ellipsoid-cylindrical, without colour reactions in Melzer's reagent or Cotton Blue. This is a rather small, but characteristic genus. In our study it was long united with Ochroporus, but the microscopical characters alone are sufficient to justify separation.

Phellinus Quél. 1886. Type: Polyporus rubriporus Quél. = P. torulosus Pers. - We found it fairly difficult to define Phellinus in the strict sense. Being rather undifferentiated and ancestral, $P$. torulosus shares characters with several genera. The binucleate mycelium and crystal hyphae (the latter character is weakly developed) connect it with Fuscoporia, and the pigmentation with Porodaedalea and Fomitiporia. The genus is best defined by enumerating the characters that it does not possess: it lacks the cyanophilousdextrinoid spores of Fomitiporia; the thick-walled and cyanophilous spore type of Porodaedalea and Ochroporus (also distinguished from them by the crystal hyphae); the macrosetae of Phellinidium; the allantoid spore type and the pigmentation of Fuscoporia. It is fortunate that the name Phellinus remains attached to an undifferentiated group. For the time being, this genus name can be used for species which do not find their natural place in the other genera. In the strict sense, Phellinus is represented in Europe only by $P$. torulosus, but the latter will be joined by many tropical species (e.g. $P$. gilvus, $P$. licnoides).

Fuscoporia Murr. 1907. Type Boletus ferruginosus Schrad. - In the present sense, Fuscoporia is a very homogeneous genus. The spores are extremely thinwalled and acyanophilous, and mostly allantoid in shape. The context is very soft-corky, and no crust or trichoderm develops on the pilei. Crystal hyphae are abundant in the tube mouths.

Fulvifomes Murr. 1914. Type: Pyropolyporus robiniae Murr. $1903=$ Phellinus robiniae (Murr.) A.Ames - Often called the P. rimosus complex, this group was not included in our study proper. Kotlaba and Pouzar (1978) have made a detailed examination of the group, and so the outlines of the genus are quite clear. Characteristic features are the large, coloured spores and complete absence of setae. For further details, the reader is referred to the revision of Kotlaba and Pouzar (1978).

Inonotopsis Parm 1973. Type: Polyporus subiculosus Peck 1879. - This genus could not be included in our study proper, because its sole representative, $I$. subiculosa, is extremely rare in Europe (Parmasto 1973, Niemelä \& Kotiranta 1983). We accept the genus because of the microscopical characteristics, but cannot establish its relationships to the other genera. These questions were discussed by Niemelä and Kotiranta (1983).

\section{New combinations and old accepted ones}

Inocutis dryophila (Berk.) Fiasson \& Niemelä, n.comb. Basionym: Polyporus dryophilus Berk., London J. Bot. 6: 321, 1874.

Inocutis rheades (Pers.) Fiasson \& Niemelä, n.comb. Basionym: Polyporus rheades Pers., Mycol. Europ. 2: 69, 1825. Type of the genus Inocutis Fiasson $\&$ Niemelä. For the typification of $P$. rheades, see Kotlaba \& Pouzar (1970).

Inocutis tamaricis (Pat.) Fiasson \& Niemelä, n.comb. Basionym: Xanthochrous tamaricis Pat., Bull. Soc. Myc. France 20: 51, 1904.

Fomitiporia erecta (David, Dequatre \& Fiasson) Fiasson, n.comb. Basionym: Phellinus erectus David, Dequatre \& Fiasson, Mycotaxon 14: 165, 1982.

Fomitiporia hartigii (All. \& Schn.) Fiasson \& Niemelä, n.comb. Basionym: Polyporus hartigii Allescher \& Schnabl, Fungi Bavarici Exsicc. 48, 1890. See Jahn (1976).

Fomitiporia hippophaeicola (H.Jahn) Fiasson \& Niemelä, n.comb. Basionym: Phellinus hippophaeicola H.Jahn, Mem. New York Bot. Garden 28: 105, 1976, 'hippophaecola'.

Fomitiporia pseudopunctata (David, Dequatre \& Fiasson) Fiasson, n.comb. Basionym: Phellinus pseudopunctatus David, Dequatre \& Fiasson, Mycotaxon 14: 171, 1982.

Fomitiporia punctata (Karst.) Murrill, Lloydia 10: 254, 1948. Poria punctata Karst., Bidr. Känned. Finlands Nat. Folk 37: 83, 1882. Polyporus punctatus Fries 1874 is a later homonym of $P$. punctatus Jungh. 1838. Syn.: Fomitiporia langloisii Murrill, North Amer. Flora 9(1): 9, 1907 (holotype: 12 Nov. 1897 Langlois 2525, NY, studied), type of the genus Fomitiporia Murrill.

Fomitiporia robusta (Karst.) Fiasson \& Niemelä, n.comb. Basionym: Fomes robustus Karst., Bidr. Känned. Finlands Nat. Folk 48: 467, 1889.

Porodaedalea chrysoloma (Fr.) Fiasson \& Niemelä, n.comb. Basionym: Polyporus chrysoloma Fries, Öfvers. K. Vet.-Akad. Förh. 18: 30, 1861. The identity of the specific name was discussed by Donk (1971).

Porodaedalea conchata (Pers.: Fr.) Fiasson \& Niemelä, n.comb. Basionym: Boletus conchatus Pers., Obs. Mycol. 1: 24, 1796. Polyporus conchatus Pers.: Fries, Syst. Mycol. 1: 376, 1821. 
Porodaedalea pini (Brot.: Fr.) Murrill, Bull. Torrey Bot. Club 32: 367, 1905. Boletus pini Brotero, Flora Lusitanica 2: 468, 1804. Daedalea pini Brot.: Fries, Syst.Mycol. 1: 336, 1821. The species was described already a year earlier, by the same name (Boletus pini Thore 1803), but having a separate type. Fries (1821) sanctioned the epithet of Brotero, which must be followed. See Donk (1974: 244). Type of the genus Porodaedalea Murrill.

Porodaedalea pilatii (Černý) Fiasson \& Niemelä, n.comb. Basionym: Phellinus pilatii Černý, Česká Mykol. 22: 2, 1968.

Ochroporus alni (Bond.) Fiasson \& Niemelä, n.comb. Basionym: Fomes igniarius (L.: Fr.) Fr. f. alni Bondarcev, Trudy Lesn. Opytn. Delu Ross. 37: 20, Fig. 1, Tab. 2, 1912. Phellinus alni (Bond.) Parm., Eesti NSV Tead. Akad. Toim. (Biol.) 25: 316, 1976. For the identity of the species, see Parmasto (1976).

Ochroporus igniarius (L.: Fr.) J.Schroet., Pilze Schles.: 487, 1888. For the typification of the epithet, see Niemelä (1975). Type of the genus Ochroporus J.Schroet.

Ochroporus laevigatus (Karst.) Fiasson \& Niemelä, n.comb. Basionym: Poria laevigata Karst., Medd. Soc. Fauna Flora Fennica 6: 10, 1881. Polyporus laevigatus Fries 1874 is a later homonym of $P$. laevigatus (Pers.) Duby 1830. For the typification, see Niemelä (1972).

Ochroporus lundellii (Niemelä) Niemelä, n.comb. Basionym: Phellinus lundellii Niemelä, Ann. Bot. Fennici 9: 51, 1972.

Ochroporus nigricans (Fr.) Fiasson \& Niemelä, n.comb. Basionym: Polyporus nigricans Fries, Syst. Mycol. 1: 375, 1821. See Niemelä (1975).

Ochroporus nigrolimitatus (Rom.) Fiasson \& Niemelä, n.comb. Basionym: Polyporus nigrolimitatus Romell, Arkiv Bot. 11(3): 18, 1911.

Ochroporus populicola (Niemelä) Niemelä, n.comb. Basionym: Phellinus populicola Niemelä, Ann. Bot. Fennici 12: 94, 1975.

Ochroporus rhamni (M.Bond.) Fiasson \& Niemelä, n.comb. Basionym: Phellinus laevigatus (Karst.) Bourd. \& Galz. f. rhamni M.Bond. in Sinadskij \& Bondarceva, Bot. Mater. Otd. Spor. Rast. Bot. Inst. Akad. Nauk SSSR 13: 230, 1960. Phellinus rhamni (M.Bond.) H.Jahn, Westfäl. Pilzbriefe 6: 89, 1967.

Ochroporus tremulae (Bond.) Fiasson \& Niemelä, n.comb. Basionym: Fomes igniarius (L.: Fr.) Fr. f. tremulae Bondarcev, Trudy Lesn. Opytn. Delu Ross. 37: 20, 22, 1912. Fomes tremulae (Bond.) Borisov, Sborn. Trudov Bol. Lesa ... 15: 85, 1940. See Niemelä (1974).

Ochroporus tuberculosus (Baumg.) Fiasson \& Niemelä, n.comb. Basionym: Boletus tuberculosus Baumgarten, Flora Lipsiensis: 635, 1790. Syn.: Ochroporus pomaceus (Pers.: S.F. Gray) Donk. Discussed by Niemelä (1982).

Phellinidium ferrugineofuscum (Karst.) Fiasson \& Niemelä, n.comb. Basionym: Poria ferrugineofusca Karst., Medd. Soc. Fauna Flora Fenn. 14: 82, 1887. Type of the genus Phellinidium (Kotl.) Fiasson \& Niemelä.
Phellinidium pouzarii (Kotl.) Fiasson \& Niemelä, n.comb. Basionym: Phellinus pouzarii Kotlaba, Česká Mykol. 22: 24, 1968.

Phellinus torulosus (Pers.) Bourd. \& Galz. Type of the genus Phellinus Quél.

Fuscoporia contigua (Pers.: Fr.) Cunningham, New Zeal. Dept. Sci. Ind. Res. Bull. 73: 4, 1948. Boletus contiguus Pers., Syn. Fung.: 544, 1801. Polyporus contiguus Pers.: Fries, Syst. Mycol. 1: 378, 1821.

Fuscoporia ferrea (Pers.) Cunningham, New Zeal. Dept. Sci. Ind. Res. Bull. 73: 7, 1948. Polyporus ferreus Pers., Mycol. Europ. 2: 89, 1825.

Fuscoporia ferruginosa (Schrad.: Fr.) Murrill, North Amer. Flora 9(1): 5, 1907. Boletus ferruginosus Schrad., Spicil. Fl. Germ.: 172, 1794. Polyporus ferruginosus Schrad.: Fries, Syst. Mycol. 1: 378, 1821.

Fuscoporia viticola (Schw. ex Fr.) Murrill, North Amer. Flora 9(1): 4, 1907. Polyporus viticola Schw. ex Fries, Elenchus Fung. 1: 115, 1828.

Fulvifomes robiniae (Murr.) Murrill, Northern Polyp.: 49, 1914. Extra-European species, type of the genus Fulvifomes Murr. See Kotlaba \& Pouzar (1978).

Fulvifomes rimosus (Berk.) Fiasson \& Niemelä, n.comb. Basionym: Polyporus rimosus Berkeley, London J. Bot. 4: 54, 1845. For the identity of the species and its typification, see Kotlaba \& Pouzar (1978).

\section{Comparison of the results of the two methods}

The results obtained from the same data matrix by these two different procedures largely coincide. The agreement was better than could theoretically be expected. The main weakness of the phenetic analysis turns out to be that some characters were incorrectly evaluated, i.e., used at the wrong level of universality (Wiley 1981), so that they masked other, more significant, characters. For instance, dextrinoid spores, presence of a core, and most styrylpyrone patterns arise in various genera and so lack good correlation with other characters (hyphal system, interbasidial secretion). They receive little significance when used at the polygeneric level, though they are actually valuable in defining some new genera. These non-generic characters create artificial links between species of different genera, introducing 'noise' into the analysis. All in all, the safest approach appears to be to use the two methods to check each other.

The comparative analysis made here helped to sort the species into groups, most of them now regarded as genera. After this rough division, the true 'face' of each genus will emerge and be refined as new species are included, more accurate comparisons are made, etc. The best diagnostic characters will be revealed by experience, and new ones are sure to be found, too. An example is the presence of the crystal hyphae in Fuscoporia: This character was found by Jahn (1967) but it was some time before its true value was appreciated by other authors. On the other hand, some characters must be treated with more caution. The cyanophily of the spores depends on the dye applied; strong cyanophily (in Fomitiporia) is always evident, and then mostly connected with dextrinoid 
spores. The weak cyanophily recently observed in Porodaedalea and Ochroporus needs further study.

\section{Affinities of the Hymenochaetales}

The last question to be considered here is that of the affinities of the Hymenochaetales. When Donk (1948) erected the family, he included both the Séries des Igniaires and des Astérostromes of Patouillard. The linking genera, Asterodon and Asterostroma, have proved to lack affinity to each other (Boidin et al. 1980). The Astérostromes have now been included in the Lachnocladiales (Reid 1965, Oberwinkler 1977), the affinities of which are totally different (GluchoffFiasson \& Kühner 1982).

In the search for related taxa, the best characteristics of the Hymenochaetales - the setae and the styrylpyrones - are of course promising clues. Structures resembling the setae are known in other groups (e.g., Marasmius), but they are now thought to be of a totally different origin (Donk 1971).

As for the styrylpyrones, their only other occurrence in fungi is in the Strophariaceae of the Agaricales (Gluchoff-Fiasson 1979). Compared with our group, the biosynthesis in the Strophariaceae shows two peculiarities. First, the accumulation of bis-noryangonine (hispidin minus one hydroxyl group) besides hispidin itself; accordingly, when hispidin engages in dimerization in more evolved genera, the 'dimer' hispidin + bis-noryangonine $=$ hypholomin A appears besides hypholomin B. Second, hispidin in some cases 'dimerizes' with arylpyrones, giving colourless fasciculins. Nevertheless, these special features do not make the styrylpyrone pattern of Strophariaceae more distant from that of poroid Hymenochaetales than the latter is from that of Hymenochaete. Another similarity exists between the Hymenochaetales and Strophariaceae: some members of the latter show darkening in $\mathrm{KOH}$ (Kühner 1980), which resembles the xanthochroic reaction of the former. In both cases this may merely reflect the occurrence of styrylpyrones (or some of their precursors), and so these two features may be linked rather than independent and correlated.

The styrylpyrone-producing Strophariaceae are lignicolous and cause a white-rot, just like the Hymenochaetales. The agaricoid habit, requiring less hardening of the fruit body (Donk 1971), could be seen as accounting concurrently for the simplicity of the hyphal system and the low yield of highly polymerized styrylpyrones ('fungal lignin'). Nevertheless, it appears less plausible that a phyletic relationship exists between the Hymenochaetales and an ochrosporous (and clamped) family of Agaricales, than that there is a 'sulfo+' evolutionary series from the Lachnocladiales and Peniophora to the Russulales (Gluchoff-Fiasson \& Kühner 1982). In the latter case, the occurrence of styrylpyrones in both the Hymenochaetales and Strophariaceae would have to be understood as mere convergence, probably arising from their shared xylophagous metabolism.

It was first believed that fungi derive their styrylpyrones from the lignin of the host. Now we know that they can produce them in cultures having glucose as the sole source of carbon. The Hymenochaetaceae and some Strophariaceae may have, independently, acquired the ability to mimic an aspect of the anabolism of the plant they prey upon. This would a gree with the fact that the most primitive of the extan1. Strophariaceae (Galerina etc., Kühner 1980) lack styrylpyrones. If these pigments appeared within the family, then of course they cannot be used as clues to its external affinities. Nevertheless (and leaving aside the question of the naturalness of the Strophariaceae), a tendency to lose the ability to synthetize sty!'ylpyrones is evident in all 'styrylpyrone+' genera and one cannot be sure that the ancestors of Galerina were not endowed with such pigments.

Acknowledgements. Our work was made possible by the help of many persons, most of them mentioned in earlier papers. We want to thank especially Mme Alix David (Lyon) and Dr. František Kotlaba (Praha) for forwarding specimens and other support. Dr. Daniel Cheyssel and Dr. Nicole Gautier (Lyon) ran the computer analyses and helped in their interpretation. Dr. Roger Moore (Coleraine, N. Ireland) kindly provided us with new information on the septal ultrastructure. We are grateful to Dr. Hermann Jahn (Detmold) for his encouragement, positive criticism and numerous proposals received during the final writing. Dr. Pekka Isoviita (Helsinki) helped with the difficult nomenclatural problems, and Mrs. Anna A. Damström, M.A., revised the English of this paper.

\section{References}

Boidin, J. 1971: Nuclear behavior in the mycelium and evolution of Basidiomycetes. - In: Petersen, R.H. (ed.), Evolution in the higher Basidiomycetes: 129-146. Knoxville.

Boidin, J., Lanquetin, P. \& Gilles, G. 1980: Application du concept biologique de l'Espèce aux Basidiomycètes: le genre Vararia (section Vararia) au Gabon. - Cryptogamie/Mycologie 1: 265-384.

Bourdot, H. \& Galzin, A. 1928: Hyménomycètes de France. - 761 pp. Sceaux.

Corner, E. 1948: Asterodon, a clue to the morphology of fungus fruit-bodies, with notes on Asterostroma and Asterostromella. - Trans. British Mycol. Soc. 31: 234345 .

Cunningham, G. 1947: Notes on the classification of the Polyporaceae. - N. Zealand J. Sci. Technol. 28A: 238251.

- 1965: Polyporaceae of New Zealand. - N. Zealand Dep. Sci. \& Industr. Res. Bull. 164: 1-304.

David, A., Dequatre, B. \& Fiasson, J.L. 1982: Two new Mediterranean Phellinus with globose, cyanophilous spores. - Mycotaxon 14: 160-174.

David, A. \& Fiasson, J.L. 1977: Spécification dans le genre Gloeophyllum Karst. (Polyporaceae): utilisation des pigments, recherche d'enzymes, interfertilités. - Bull. Mens. Soc. Linn. Lyon 46: 304-320.

Donk, M. 1948: Notes on Malesian fungi 1. - Bull. Bot. Gard. Buitenzorg III 17: 473-482.

- 1960: The generic names proposed for Polyporaceae. Persoonia 1: $173-302$.

- 1962: The generic names proposed for Polyporaceae. Additions and corrections. - Persoonia 2: $201-210$.

- 1964: A conspectus of the families of Aphyllophorales. - Persoonia 3: 199-324.

- 1971: Progress in the study of the classification of the higher Basidiomycetes. - In: Petersen, R.H. (ed.), Evolution in the higher Basidiomycetes: 3-24. Knoxville. 
- 1974: Check list of European polypores. - Verh. Koninkl. Nederl. Akad. Wetensch. Afd. Natuurk. Tweede Reeks 62: 1-469.

Fiasson, J.L. 1982: Distribution of styrylpyrones in the basidiocarps of various Hymenochaetaceae (Aphyllophorales, Fungi). - Biochem. Syst. \& Ecol. 10: 289296.

- 1983: Contribution synthétique a la taxinomie phylétique des Hyménochétacées porées d'Europe, spécialement du genre Phellinus. - 73 pp. Thesis 83-13, Univ. ClaudeBernard Lyon I.

Fiasson, J.L. \& Bernillon, J. 1977: Identification chimique de styryl-pyrones chez quatre hyménochétacées (Champignons, Aphyllophorales). - J. Canad. Bot. 55: 2984-2986.

- 1983: Recherche d'activités enzymatiques dans les mycéliums d'Hyménochétacées porées d'Europe: apport taxinomique. - Bull. Soc. Mycol. France 99: 93-107.

Fiasson, J.L. \& David, A. 1983: Approche taximétrique des hyménochétacées porées d'Europe (Champignons, Aphyllophorales). - J. Canad. Bot. 61: 442-451.

Fiasson, J.L., Gluchoff-Fiasson, K. \& Steglich, W. 1977: Über die Farb- und Fluoreszenzstoffe des Grünblättrigen Schwerelkopfes (Hypholoma fasciculare, Agaricales) - Chem. Bericht 110: 1047-1057.

Fries, E. 1821: Systema Mycologicum 1. - 520 pp. Lundae.

Génermont, M. 1980: Trois conceptions modernes en taxinomie: Taxinomie cladistique, taxinomie évolutive, taxinomie phénétique. - Ann. Biologie 19: 19-40.

Gilbertson, R., Lombard, F. \& Canfield, E. 1975: Gum guaiac in field tests for phenol oxidases of wood-rotting fungi and other Basidiomycetes. - USDA For. Serv. Res. Paper FPL 269: 1-23.

Gluchoff-Fiasson, K. 1979: Contribution à la chimiotaxinomie des Hyménomycètes: pigments des Tricholomataceae Roze et des Strophariaceae Sing. \& Smith. -216 pp. Thesis, Univ. Claude Bernard Lyon I.

Gluchoff-Fiasson, K. \& Kühner, R. 1982: Le principe responsable du bleuissement au réactif sulfovanillique des cystides et laticiferes de divers Homobasidiomycètes: intérêt taxinomique. - Compt.-Rendus Acad. Sci. Paris 294: 1067-1071.

Hegnauer, R. 1976: Accumulation of secondary products and its significance for biological systematics. - In: Luckner, M. (ed.), Secondary metabolism and coevolution: 45-76. Leipzig.

Jahn, H. 1967: Die resupinaten Phellinus-Arten in Mitteleuropa... - Westfälische Pilzbriefe 6: 37-108.

- 1976: Phellinus hartigii (All. \& Schn.) Pat. und Ph robustus (P.Karst.) Bourd. \& G. - Westfälische Pilzbriefe 11: $1-15$.

- 1978: Die Gattung Onnia P.Karst., Filzporlinge. Westfälische Pilzbriefe 11: 79-93.

- 1981: Die resupinaten Phellinus-Arten in Mitteleuropa.. Nachträge 1967-1981 - Bibl. Mycol. 81: 109-151.

Jülich, W. 1981: Higher taxa of Basidiomycetes. - Bibl. Mycol. 85: 1-485.

Kendrick, W. \& Weresub, L. 1966: Attempting NeoAdansonian computer taxonomy at the ordinal level in Basidiomycetes. - Syst. Zool. 15: 302-329.

Kotlaba, F. 1968: Phellinus pouzarii sp.nov. - Česká Mykol. 22: 24-31.

Kotlaba, F. \& Pouzar, Z. 1970: Revision of the original material of Phellinus sulphurascens Pil., Xanthochrous glomeratus spp. heinrichii Pil. and Polyporus rheades Pers. (Hymenochaetaceae). — Ceská Mykol. 24: 146152.

- 1978: Notes on the Phellinus rimosus complex (Hymenochaetaceae). - Acta Bot. Croatica 37: 171182.

Kühner, R. 1950a: Absence de boucles chez les Basidiomycètes de la série des Igniaires et comportement nucléaire dans le mycélium des Hymenochaete Lév. -
Compt.-Rendus Acad. Sci. Paris 230D: 1606-1608.

- 1950b: Comportement nucléaire dans le mycélium des Polypores de la série des Igniaires. - Compt.-Rendus Acad. Sci. Paris 230D: 1687-1689.

- 1980: Les Hyménomycètes agaricoides. - 1027 pp. Lyon.

Lebart, L., Morineau, A. \& Tabard, N. 1977: Techniques de description statistique - méthodes et logiciels pour l'analyse de grands tableaux. $-175 \mathrm{pp}$. Paris

Moore, R. 1980: Taxonomic significance of septal ultrastructure in the genus Onnia Karsten (Polyporinae Hymenochaetaceae). - Bot. Not. 133: 169-175.

Niemelä, T. 1972: On Fennoscandian polypores 2. Phellinus laevigatus (Fr.) Bourd. \& Galz. and P. lundellii Niemelä, n.sp. - Ann. Bot. Fennici 9: 41-59.

- 1974: On Fennoscandian polypores 3. Phellinus tremulae (Bond.) Bond. \& Borisov. - Ann. Bot. Fennici 11: 202-215.

- 1975: On Fennoscandian polypores 4. Phellinus igniarius, P. nigricans and P. populicola, n.sp. - Ann. Bot. Fennici 12: 93-122.

- 1977: On Fennoscandian polypores 5. Phellinus pomaceus. - Karstenia 17: 77-86.

- 1980: On Fennoscandian polypores 7. The Genus Pycnoporellus. - Karstenia 20: 1-15.

- 1982: Taxonomic notes on the polypore genera Antrodiella, Daedaleopsis, Fibuloporia and Phellinus. - Karstenia 22: 11-12

Niemelä, T. \& Kotiranta, H. 1983: Polypore survey of Finland 3. The genera Coltricia, Inonotopsis, Inonotus and Onnia. - Karstenia 23: 15-25.

Nobles, M. 1948: Studies in forest pathology 6 . Identification of cultures of wood-rotting fungi. Canad. J. Res. 26C: $281-481$.

- 1965: Identification of cultures of wood-inhabiting Hymenomycetes. - Canad. J. Bot. 43: 1097-1139.

Oberwinkler, F. 1977: Das neue System der Basidiomyceten. - In: Frey, W., Hurka, H. \& Oberwinkler, F. (eds.), Beiträge zur Biologie der niederen Pflanzen: 59-105.

Parmasto, E. 1973: Novyi rod Inonotopsis Parm. (sem. Hymenochaetaceae). - Folia Crypt. Estonica 2: $11-$ 13 .

- 1976: Studies on Yakutian fungi 2. Ganodermataceae, Hymenochaetaceae, Polyporaceae s.str. - Eesti NSV Tead. Akad. Toim. (Biol.) 25: 316-321.

Parmasto, E. \& Parmasto, I. 1979: The xanthochroic reaction in Aphyllophorales. - Mycotaxon 8: 201-232.

Pasteur, G. \& Pasteur, N. 1980: Les critères biochimiques et l'espèce animale. - In: Bocquet, C., Génermont, J. \& Lamotte, M. (eds.), Les problèmes de l'espèce dans le Règne Animal 3: 99-150. Paris.

Patouillard, N. 1900: Essai taxinomique sur les familles et les genres des Hyménomycètes. - 184 pp. Thesis, Univ. Paris.

Pilát, A. 1936-1942: Polyporaceae. - In: Kavina, C. \& Pilát, A. (eds.), Atlas des champignons de l'Europe 3: $1-624,374$ pls. Praha.

Reid, D. 1965: A monograph of the stipitate stereoid fungi. - 388 pp. Wien.

Ryvarden, L. 1978: The Polyporaceae of North Europe 2. Inonotus to Tyromyces. - Pp. 219-507. Oslo.

- 1982: The genus Hydnochaete (Hymenochaetaceae). Mycotaxon 15: 425-447.

Ryvarden, L. \& Johansen, I. 1980: A preliminary polypore flora of East Africa. - 636 pp. Oslo.

Singer, R. 1975: The Agaricales in modern taxonomy. 3rd edition. - 912 pp. Vaduz.

Wiley, E. 1981: Phylogenetics: the theory and practice of phylogenetic systematics. - $439 \mathrm{pp}$. New York.

Yokoyama, A., Natori, S. \& Aoshima, K. 1975: Distribution of tetracyclic triterpenoids of lanostane group and sterols in the higher fungi, especially of the Polyporaceae and related families. - Phytochemistry 14: 487-497. 